Abstracta Iranica Abstracta Iranica

Revue bibliographique pour le domaine irano-aryen

Volume 32-33 | 2013

Comptes rendus des publications de 2009-2010

\title{
Hirotake Maeda. The Household of Allahverdi Khan: an Example of Patronage Network in Safavid Iran
}

\section{Giorgio Rota}

\section{(2) OpenEdition \\ 1 Journals}

\section{Electronic version}

URL: http://journals.openedition.org/abstractairanica/40668

DOI: 10.4000/abstractairanica.40668

ISSN: 1961-960X

Publisher:

CNRS (UMR 7528 Mondes iraniens et indiens), Éditions de l'IFRI

\section{Printed version}

Date of publication: 1 December 2013

ISSN: 0240-8910

\section{Electronic reference}

Giorgio Rota, "Hirotake Maeda. The Household of Allahverdi Khan: an Example of Patronage Network in Safavid Iran », Abstracta Iranica [Online], Volume 32-33 | 2013, document 245, Online since 01 July 2016, connection on 26 September 2020. URL : http://journals.openedition.org/abstractairanica/ 40668 ; DOI : https://doi.org/10.4000/abstractairanica.40668

This text was automatically generated on 26 September 2020.

Tous droits réservés 


\title{
Hirotake Maeda. The Household of Allahverdi Khan: an Example of Patronage Network in Safavid Iran
}

\author{
Giorgio Rota
}

\section{REFERENCES}

Hirotake Maeda. « The Household of Allahverdi Khan: an Example of Patronage Network in Safavid Iran ", in : Florence Hellot-Bellier et Irène Natchkebia, éds., La Géorgie entre Perse et Europe. Paris, L'Harmattan, 2009, p. 49-66.

1 The author returns to a subject on which he has already made important contributions: Caucasian golāms in Safavid service. His investigation focuses on Allāhverdī Hāan, one of the most prominent and well-known golàms, who is set in the new light provided by the recent rediscovery of the lost third volume of Faḍlī Hūzāāī Eșfahānī's Afdalo't-tavārīH. Maeda starts by sketching a biography of the Khan, about whom the rediscoverd volume provides many a detail. He then reviews the information from this same source about five members of the Khan's entourage: two Caucasians, a Turk, a Tajik and an officer of mixed Turk/Tajik ancestry (who was a cousin of Faḍlī Hūuānī Eșfahānī). One of these, Mīkā'il Beyg (a cousin of the Khan) has apparently never been mentioned in other sources from the period. Maeda describes the importance of patronage, personal connections and family heritage in these men's careers, which cut across the supposed barriers existing between Turks, Tajiks, and golāms - recent scholarship sees this supposition about Safavid society as being obsolete. It is not clear to the present reviewer, however, whether Maeda is claiming that the Afḍalo't-tavārï alone suffices for moving beyond this old-fashioned portrayal of relations among the various ethnic components of Safavid society. He writes, "the newly found volume III [...] contributes much to the clarification of those connections which were not observed in other Persian sources" (p. 64). In this case, we cannot concur with him. 
2 This is a very useful and interesting article, especially since a critical edition of the Afd alo't-tavārīH is not yet available. Nonetheless, this contribution needs severe editing: the English text is sometimes obscure, and misprints are frequent. For example, we come upon several instances of khajja instead of khașsa). Maeda oddly lists his own article "Parsadan Gorgijanidze's Exile in Shushtar [...]" as forthcoming in a miscellaneous volume to come out in London (n. 20, p. 56 and p. 66), whereas it has already been published in Journal of Persianate Studies, 1/II (2008), p. 218-229.

\section{AUTHORS}

\section{GIORGIO ROTA}

Institut für Iranistik, Wien 